\title{
Seasonal and Age Changes in Leukocyte Indices in Shrews
}

\author{
Elżbieta WOŁK
}

\begin{abstract}
Wołk E., 1981: Seasonal and age changes in leukocyte indices in shrews. Acta theriol., 26, 12: 219-229 [With 3 Tables \& 5 Figs.].

Examination was made of WBC (white blood cells) count and the percentage and absolute contents of the different forms of leukocytes in 369 individuals of Sorex araneus Linnaeus, 1758, and 28 representatives of Sorex minutus Linnaeus, 1776. Minimum WBC count occurs in young adults of $S$. araneus in January-February: $0.85 \times 10^{3} / \mu 1$, maximum value in young adults in July: $3.14 \times 10^{3} / \mu$ l. In young adults of $S$. minutus in autumn $W B C$ value is $1.10 \times 10^{3} / \mu 1$, and in old adults in spring $0.97 \times 10^{3} / \mu l$. WBC counts are thus very low in shrews. When $S$. araneus and $S$. minutus were compared it was found that the smaller mean body weight of $S$. minutus corresponded to the lower WBC value and greater $R B C$ (red blood cells) counts. WBC count falls in $S$, araneus from the maximum values in young adults in summer to a minimum during the winter and increases again slightly in old adults in spring, and thus the seasonal and age tendencies of variations in number of $W B C s$ and $R B C s$ are reversed. The percentage of lymphocytes is higher in young adults than in old adults, this form of leukocyte predominating in both these groups. Conversely, the percentage of neutrophils is higher in old adults. The juvenile forms of granulocytes occur in the peripherai blood of shrews, their numbers reaching a peak during the autumn-winter months.

[Mammals Res. Inst., Polish Acad. Sci., 17-230 Białowieża, Poland].
\end{abstract}

\section{INTRODUCTION}

There are no data in hematological literature on the leukocyte system in mammals of the genus Sorex. Indices given for other insectivorous animals include the hedgehog Erinaceus europaeus (Suomalainen, 1953, Biörck et al., 1956, Kekić \& Mladjenović, 1969, Kekić, 1970), and from the Soricidae family there are very fragmentary data on the Indian musk shrew Suncus murinus, given by Balakrishnan et al. (1974). Shrews of the genus Sorex, which are amongst the smallest mammals, and in addition do not hibernate, are characterized by specific histological structure of the hematopoietic tissue (Perkowska, 1963) and very marked erythrocytosis (high $R B C$ and Hct values), particularly in winter (Wołk, 1974). In the present study results are given of studies on the leukocyte system in the common shrew Sorex araneus Linnaeus, 1758, and the pigmy shrew Sorex minutus Linnaeus, 1776. 


\section{MATERIAL AND METHODS}

Studies were made of 369 individuals of Sorex araneus, 12 of which were young nestlings, and of 28 representatives of Sorex minutus. The animals were segregated into young and old adults, depending on the appearance of the coat, degree of wear of the teeth and degree of development of the gonads. All the shrews examined were caught in the Bialowieża Primeval Forest and were the same individuals as those used for studies on erythrocyte indices (Wolk, 1974). The shrews were caught in every month of the year over the course of their life cycle.

Blood samples were taken from the jugular vein between 8.30 and 11.00 a.m. from animals anaesthetized with ether. Leukocytes $(W B C)$ were counted in a Bürker chamber. The percentage of the various forms of leukocytes was determined from blood smears stained by the Pappenheim method, on the basis of microscopic ubservation of 100 cells in each preparation. A smaller number, from 50-100 cells, was examined only in 26 individuals in which $W B C$ value was very low. The absolute numbers of the various forms of leukocytes per $1 \mu \mathrm{l}$ and the ratio of lymphocytes to neutrophils $(L / N)$ were then calculated. In $S$. minutus the small amount of blood did not always make it possible to indentify all indices in each animal. In order to compare mean $W B C$ counts from monthly samples over the shrews' life cycle variance analysis and a new multiple range test were used. The total number of different forms of leukocytes was compared by the $t$ - test for two independent groups, and the percentage composition of leukocytes between groups of young and old adults was compared by means of the $t$ - test for percentage values.

\section{RESULTS AND DISCUSSION}

\subsection{Nest Period}

The possibility of hematological studies on young shrews still living in nests are very limited, on account of the small body dimensions of these animals. The body weight of the shrews examined varied from $0.398 \mathrm{~g}$ on the first day of life to $4.850 \mathrm{~g}$ on the ninth day. On the eighth day of nest life the number of $W B C$ was $0.833 \times 10^{3} / \mu 1$, and thus 13 days before leaving the nest the number of leukocytes was more than three times lower than during the first month of life outside the nest. The leukocyte formula during the first nine days of the shrew's life (Table 1) differs distinctly from the picture observed in these mammals during the period after leaving the nest (Table 2). The WBC picture is decidedly lymphocytic, the $L / N$ index high, far higher than after leaving the nest. A striking feature is the absence of eosinophils and monocytes, and the relatively frequent occurrence of basophils, which very rarely occur in adult shrews. There is a high percentage of the juvenile forms of granulocytes, as is the case in young adults during the winter months. 


\subsection{Seasonal and Age Changes}

Variations in the total number of leukocytes in $1 \mu \mathrm{l}$ of blood in the common shrew during the period after leaving the nest and over the seasonal-age cycle are shown in Fig. 1 and Table 2. WBC count in very young shrews increases from June to attain a maximum in July (3.14X $\left.\times 10^{3}\right)$, and next as from August decreases to a minimal level $\left(0.85 \times 10^{3}\right)$

Table 1

Total number and the percentage of different forms of leukocytes in the blood of the nestlings of $S$. araneus.

\begin{tabular}{lrrrrr}
\hline & \multicolumn{5}{c}{ Age, days } \\
\cline { 2 - 6 } & 1 & 3 & 5 & 8 & 9 \\
\hline WBC $\times 10^{3} / \mu 1$ & - & - & - & $0.833 \pm 0.287$ & - \\
I.ymphocyte, $\%$ & 87.5 & $90.5 \pm 5.2$ & 90 & - & 86 \\
Monocytes, \% & 0 & 0 & 0 & - & 0 \\
Juvenile granulocytes, \% & 0 & $5.75 \pm 2.9$ & 7 & - & 6.5 \\
Neutrophils, \% & 11.0 & $3.5 \pm 2.3$ & 2 & - & 5 \\
Eosinophils, \% & 0 & 0 & 0 & - & 0 \\
Basophils, \% & 1.5 & $0.25 \pm 0.5$ & 1 & - & 2.5 \\
L/N & 7.9 & 25.9 & 45 & - & 17.2 \\
$\mathrm{~N}$ & 2 & 4 & 1 & 3 & 2 \\
\hline
\end{tabular}

during the winter months. In old adults as from April $W B C$ value rises but does not reach the maximum level found in young shrews in July. The most striking feature of $W B C$ in shrews is the small number of leukocytes in peripheral blood, lower than the corresponding values of this index in such rodents as the bank vole, common vole, or root vole. In 25 sexually active old adults of Sicista betulina, however, similar in body weight to shrews, WBC count is on an average $1.75 \times 10^{3} / \mu$ l (author's own data) and thus the values are very similar. In a tropical species of Soricinae, the Indian musk shrew, as many as $15.22 \times 10^{3}$ leukocytes were found in $1 \mu \mathrm{l}$ of blood (Balakrishnan et al., 1974). For the hedgehog in its hibernating state $W B C$ count is $3.59 \times 10^{3}$, and the maximum value of this index $\left(8.78 \times 10^{3}\right)$ occurs in autumn (Kekić, 1970). Only $0.83 \times$ $\times 10^{3} / \mu 1$ leukocytes were found in the blood of hedgehogs in a state of artificial euthermia during the winter period (Kekić \& Mladjenović, 1969). It may therefore be assumed that such distinct "leukopenia" in shrews in winter is connected with the absence of winter sleep in these mammals.

Comparison of variation curves of $R B C$ (Wołk, 1974) and WBC over the seasonal-age cycle of common shrews would appear very interesting (Fig. 1). From June to August they follow an almost ideally parallel 


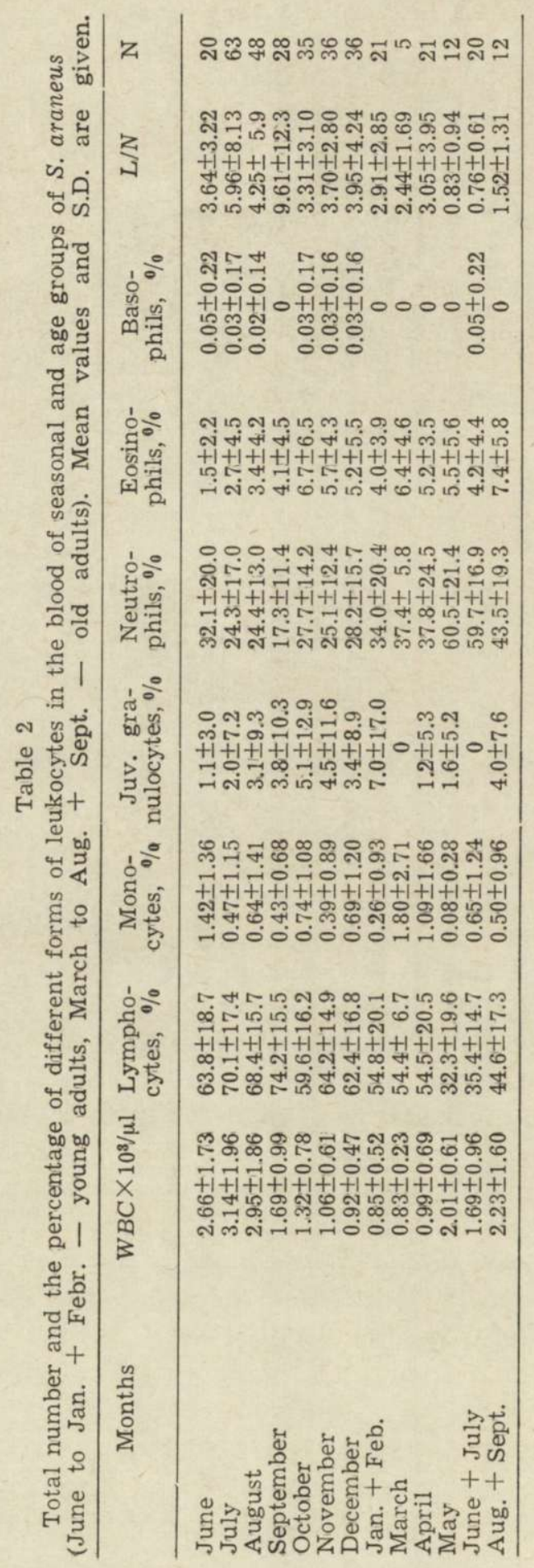


course: in very young animals during the first weeks of life the number of cell elements increases in peripheral blood, but declines in August, probably as the result of the entry into the population of young shrews from the second litter. These curves next separate, since $R B C$ count increases to a maximum in January-February, and WBC count regularly

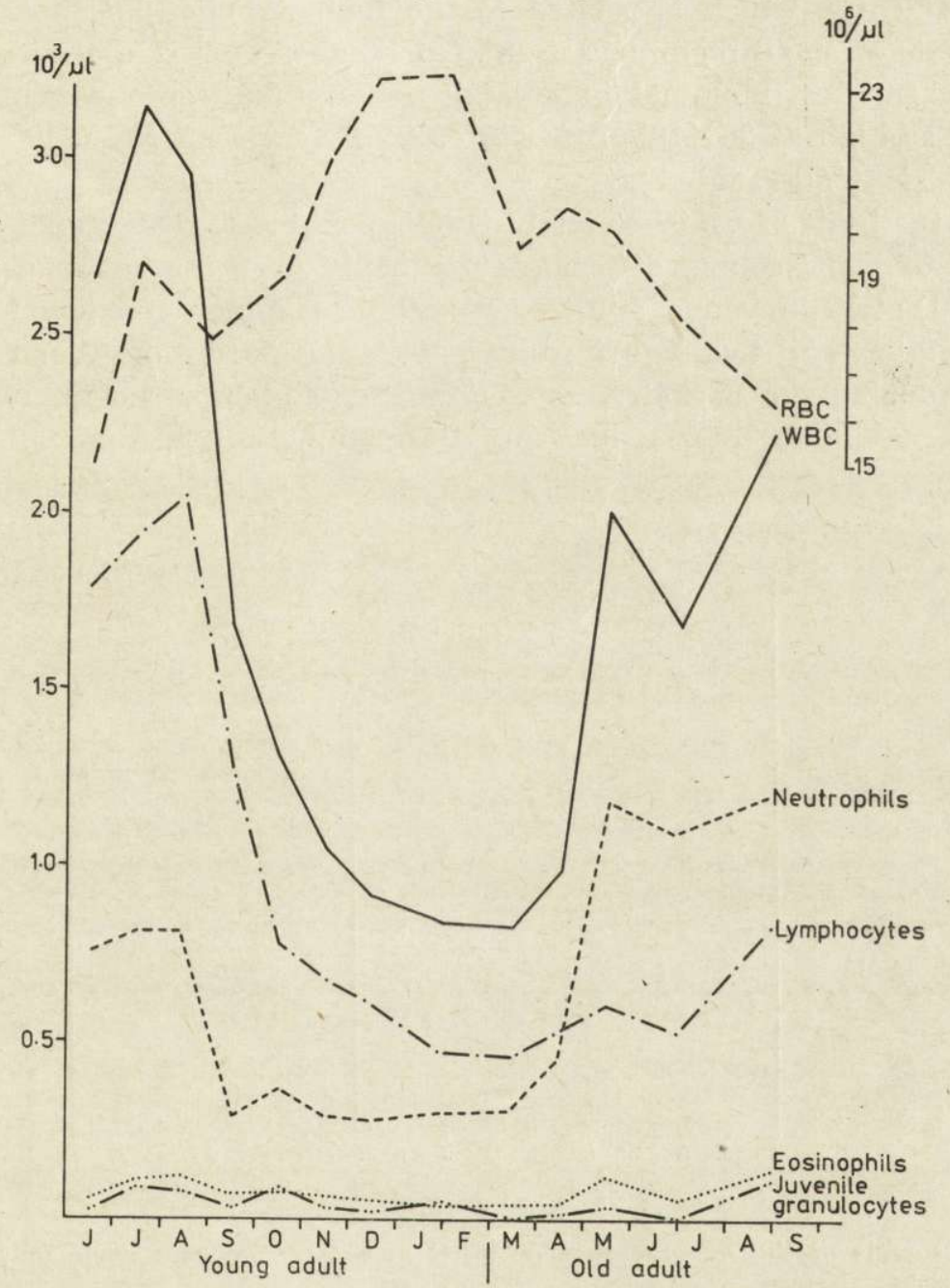

Fig. 1. Seasonal and age changes of total $(W B C)$ and differential number of leukocytes and total number of erythrocytes $(R B C)$ in the blood of $S$. araneus.

decreases during the same period. In old adults in spring reverse tendencies also occur: reduction in $R B C$ and increase in $W B C$. It would therefore appear that there is a distinct complementary relation between these two values. The intensified thermoregulation of shrews in winter, connected with intensive gas exchange requires so great a number of 
erythrocytes that it brings about a decrease in the number of the other basic morphotic elements of blood, in order to prevent harmful condensation of blood, especially as the absolute blood volume decreases in shrews in winter (Wołk, 1974). The generally low WBC value in shrews can be explained in an analogical way. In view of the considerable number of $R B C \mathrm{~S}$, which is related to the higher weight-specific metabolic demands of small mammals, a limited number of WBCs occurs in them. In the smallest mammal in Poland, Sorex minutus, in which $R B C$ value is as high as $26 \times 10^{6} / \mu \mathrm{l}$ in winter (Wołk, 1974), WBC value oscillates round $1 \times 10^{3} / \mu \mathrm{l}$ (Table 2 ).

On the basis of variance analysis it is possible to distinguish in shrews levels of WBC counts differing statistically over the seasonal-age cycle $(p<.01)$ : two in young adults, i.e. high in summer and low in autumn and winter, and two in old adults - low in March and April and high again during the period from May to September, although it does not attain maximum $W B C$ values found for young adults (Fig. 2).

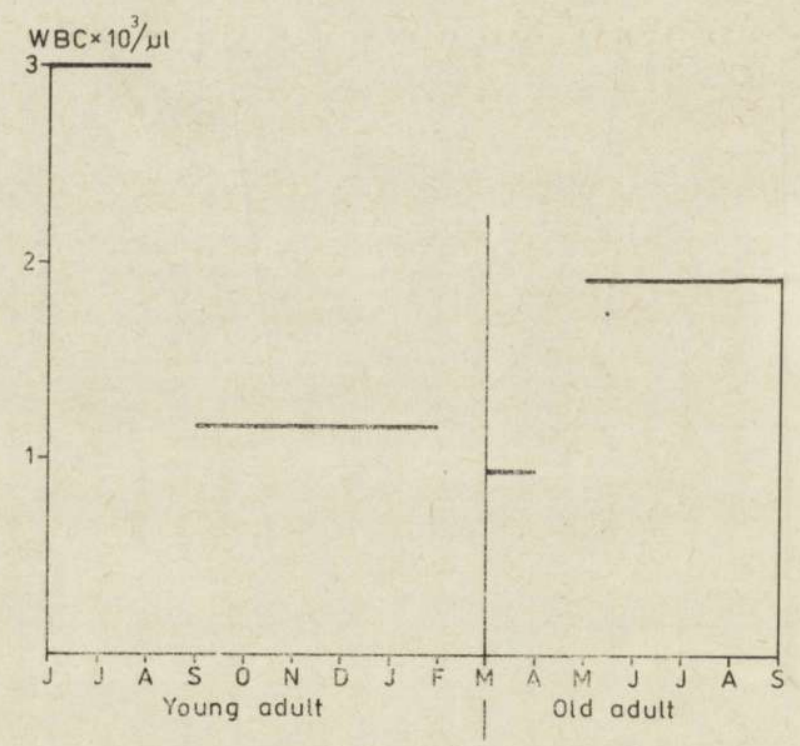

Fig. 2. Levels of the mean values of $W B C$ in the sesonal-age cycle of $S$. araneus.

The total numbers of lymphocytes and neutrophils in $\mu \mathrm{l}$ of blood exhibit distinct parallelism with the number of $W B C_{S}$ over the seasoralage cycle (Fig. 1). The number of lymphocytes decreases in young shrews during the period from August to January-February $(p<.001)$ and then increases in old adults (differences between January-February in young adults and August-September in old adults are significent, 
$p<.001)$. The number of neutrophils, high in young shrews in June, July and August, decreases during the period from August to September $(.002<p<.005)$, is maintained on a low level up to March, then rises in old adults (differences between January-February and May are significant, $p<.001$ ) (Fig. 1). The absolute numbers of the other forms of leukocytes do not significantly alter over the seasonal-age cycle of shrews.

When three values in the genus Sorex are considered, i.e. body weight, $R B C_{\mathrm{S}}$ and $W B C_{\mathrm{S}}$, it can be seen that the lesser mean body weight in Sorex minutus corresponds to the greater number of $R B C$ and smaller number of $W B C$ in $1 \mu \mathrm{l}$ of blood, than is the case with Sorex araneus (Fig. 3). It would seem, in the light of what is known of hematological indices in mammals of different body weights, that this is a general tendency.

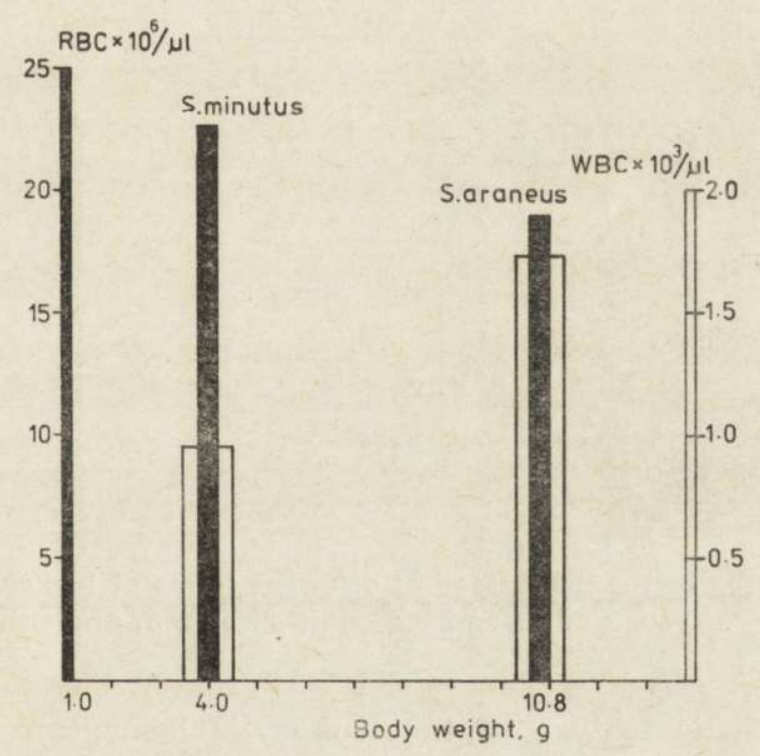

Fig. 3. Relation between average body weight of two species of Sorex and $R B C$ and WBC counts. Samples from May and June (old adults).

The percentage of the differential forms of leukocytes in $S$. araneus and $S$. minutus is given in Tables 2 and 3 . When comparing young and old adults of the common shrew (Fig. 4) it can be seen that in young animals the percentage of lymphocytes is higher than in old adults $(0.2<$ $<p<.05$ ), although in both groups they are the dominating form. The percentage of neutrophils is correspondingly higher in old adults $(.01<$ $<p<.02)$. The effect of this is the difference in $L / N$ index, the value 
being significantly higher in young shrews $(.001<p<.002)$. The other forms of leukocytes, however, do not differ significantly in these two age groups. The difference in the percentage composition of leukocytes in young and old adults of $S$. minutus is similar (Table 2). The lymphocyte profile of the hemogram is characteristic of small mammals. In Suncus murinus viridescens, however a high percentage of neutrophils was found $(64.7 \%)$ and a far lower percentage of lymphocytes $(17.8 \%)$, with a relatively high percentage of the other forms of leukocytes (Balakrishnan et al., 1974), which in the genus Sorex occur in negligible amounts.
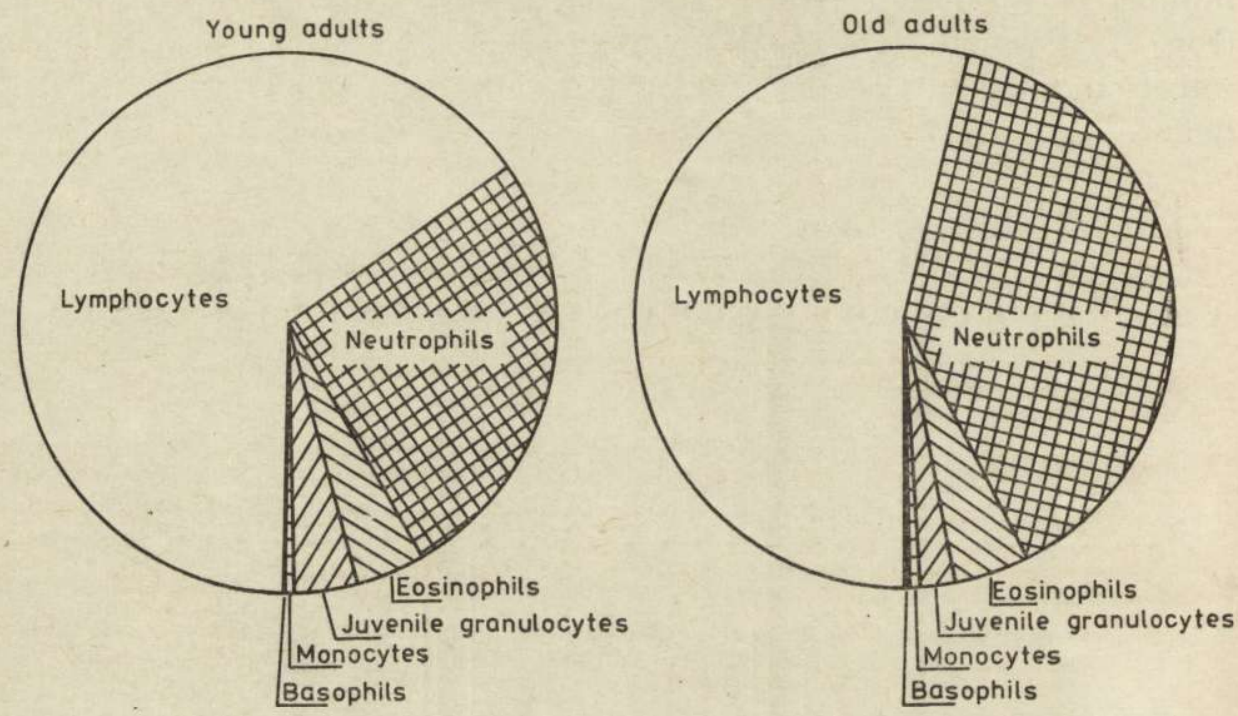

Fig. 4. Comparison of the percentage of different forms of leukocytes in the blood of young adult and old adult shrews, $S$. araneus.

A characteristic feature of the leukocytic hemogram of peripheral blood in shrews is the occurrence of the juvenile forms of granulocytes, beginning with myeloblasts, through promyelocytes, myelocytes, metamyelocytes and the most numerous non-segmented forms. With the exception of a small number of the latter, juvenile granulocytes in mammals in the normal physiological state do not exceed the medullary barrier, and the occurrence of a large number of granulocytes precursors in peripheral blood takes place in neoplastic disorders of the hematopoietic system. In a natural population of common shrews juvenile granulocytes forms, in extreme cases in different individuals, as much as $70 \%$ of all forms of leukocytes. In young adults there are two peaks in the mean percentage contents of juvenile granulocytes - in autumn 
Table 3

Total number and the percentage of different forms of leukocytes in the blood of seasonal and age groups of $S$. minutus (mean values and S. D. are given).

\begin{tabular}{|c|c|c|c|}
\hline & $\begin{array}{l}\text { Young adult, } \\
\text { Autumn }\end{array}$ & $\begin{array}{l}\text { Young adult, } \\
\text { Winter }\end{array}$ & $\begin{array}{l}\text { Old adult, } \\
\text { Spring }\end{array}$ \\
\hline$W B C \times 10^{3} / \mu 1(\mathrm{~N})$ & $1.10 \pm 0.08$ & - & $0.97 \pm 0.31$ \\
\hline $\begin{array}{l}\text { Lymphocytes, } \% \\
\text { cells/ } \mu 1\end{array}$ & $\begin{array}{r}53.9 \pm 16.9 \\
656.7 \pm 71.0\end{array}$ & $45.5 \pm 23.1$ & $29.7 \pm 9.9$ \\
\hline $\begin{array}{l}\text { Monocytes, } \% \\
\text { cells } / \mu 1\end{array}$ & $\begin{array}{l}0.2 \pm 0.6 \\
8.0 \pm 11.3\end{array}$ & 0 & $\underline{0}$ \\
\hline $\begin{array}{l}\text { Juv. granulocytes, } \% \\
\text { cells } / \mu 1\end{array}$ & $\begin{array}{r}19.0 \pm 18.4 \\
128.3 \pm 27.2\end{array}$ & $21.7 \pm 27.8$ & $32.5 \pm 20.4$ \\
\hline $\begin{array}{l}\text { Neutrophils, } \% \\
\text { cells } / \mu 1\end{array}$ & $\begin{array}{r}21.5 \pm 9.5 \\
218.3 \pm 11.1\end{array}$ & $28.5 \pm 13.6$ & $34.5 \pm 17.5$ \\
\hline $\begin{array}{l}\text { Eosinophils, \% } \\
\text { cells } / \mu 1\end{array}$ & $\begin{array}{r}5.2 \pm 3.8 \\
84.7 \pm 20.4\end{array}$ & ${ }^{4.3 \pm 2.9}$ & $3.3 \pm 2.8$ \\
\hline $\begin{array}{l}\text { Basophils, } \% \\
\text { cells/ } / \mu 1\end{array}$ & $\begin{array}{l}0.1 \pm 0.3 \\
4.0 \pm 5.6\end{array}$ & $\underline{0}$ & 0 \\
\hline $\begin{array}{l}L / N \\
N\end{array}$ & $3.6 \pm 3.2$ & $1.9 \pm \frac{1}{6} 1.5$ & $1.3 \pm 1.1$ \\
\hline
\end{tabular}

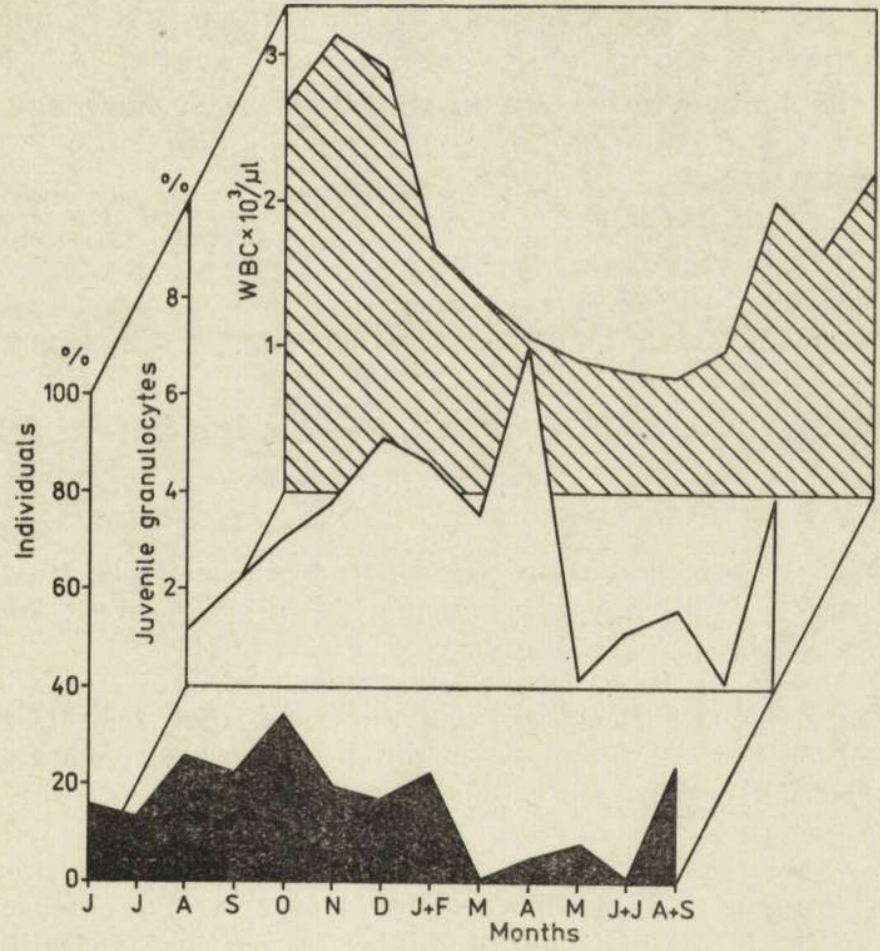

Fig. 5. WBC count, per cent of juvenile granulocytes and per cent of common shrew individuals possessed of juvenile granulocytes in the seasonal-age cycle of $S$. araneus. 
(Oct.) and in winter (Jan. - Febr.), but in the case of old adults the period is August-September (Fig. 5). The percentage of individuals in which juvenile granulocytes were found is similarly highest in October in young shrews and in August-September in old adults (Fig. 5). The autumn-winter peak may be explained as due to overburdening of the hematopoietic system by intensified production of erythrocytes during this period of the shrews' life, and in consequence in failure to maintain the rate of granulocyte maturation. The autumn peak in old adults is more difficult to explain. It may be induced by increased mobilization of granulocytes connected with senile changes.

Shrews are thus characterized by low WBC count which is probably connected with their extremely small body dimensions, and with the great number of erythrocytes, and thus with the necessity for maintaining equilibrium between the numbers of morphotic elements of peripheral blood. Tendencies to variation in the number of WBCs and $R B C s$ are opposite to each other in shrews and the minimum WBC count occurs during the winter months of January-February, when $R B C$ value reaches a maximum. The blood profile is lymphocytic; the younger the shrews, the greater the percentage of lymphocytes. $L / N$ index is significantly higher in young adults than in old adults. A characteristic feature of the leukocyte system in shrews is the occurrence of juvenile granulocytes, mainly metamyelocytes and nonsegmented granulocytes. The autumn-winter maximum intensification of these changes is probably due to the hematopoietic system being overburdened by very high erythrocytosis.

Acknowledgements: I wish to thank H. Okolów, M. Sc. for excellent technical assistance.

\section{REFERENCES}

1. Balakrishnan M., Ambikatmajan Nair G. N. \& Alexander K. M., 1974: A study on some aspects of the physiology of the Indian musk shrew, Suncus murinus viridescens (Blyth). J. Anim. Morph. Physiol., 21: 98-106.

2. Biörck G., Johansson B. \& Veige S., 1956: Some laboratory data on hedgehogs, hibernating and non-hibernating. Acta Physiol. Scand., 37: 281-294.

3. Kekić H., 1970: Sezonske promjene nekih elemenata krvi (hemogram) i koštane srži (mijelogram) u Erinaceus europaeus L. Godiš. Biol. inst. Univ. u Sarajevu, 23: $33-75$.

4. Kekić H. \& Mladjenović O., 1969: Leucocytes and mutual relation among the particular forms of leucocytes in the blood of Erinaceus europaeus L. in the state of artificial euthermia during winter season. Bull. Scientifique, Sec. A, 14: 7 .

5. Perkowska E., 1963; Investigations in blood tissue of some Micromammalia. Acta theriol., 7: $69-78$. 
6. Suomalainen P., 1953 (1954): Further investigations on the physiology of hibernation. S. B. Finn. Akad. Wiss., 131-144.

7. Wolk E., 1974: Variations in the hematological parameters of shrews. Acta theriol., 19: $315-346$.

Accepted, November 23, 1981.

\section{Elżbieta WOEK}

\section{SEZONOWE I WIEKOWE ZMIANY WSKAŹNIKOW LEUKOCYTOWYCH U RYJOWEK}

Streszczenie

Zbadano liczbę leukocytów w $1 \mu \mathrm{l}$ krwi obwodowej (WBC) oraz procentową i bezwzględną zawartość poszczególnych form leukocytów u 369 osobników Sorex araneus Linnaeus, 1758 (w tym u 12 młodych z okresu gniazdowego) i 28 przedstawicieli Sorex minutus Linnaeus, 1776.

Stwierdzono, że u obu tych gatunków ryjówek liczba leukocytów w 1 ul krwi jest niska. U S. araneus maksymalna wartość $W B C$ wynosi $3.14 \times 10^{3} / \mu 1$, minimalna $0.85 \times 10^{3} / \mu 1$, u $S$. minutus maksymalna wartość $1.10 \times 10^{3} / \mu 1$, minimalna $0.97 \times 10^{3} / \mu$ l, (Tabela 2 i 3 ). Wartość $W B C$ u młodych ryjówek aksamitnych, poczynając od okresu gniazdowego (Tabela 1), rośnie, osiągając maksimum w lipcu, od sierpnia spada do minimum w styczniu-lutym i ponownie wzrasta u przezimków od kwietnia począwszy, nie osiągając jednak wartości maksymalnych (Tabela 2, Fig. 1 i 2). Tendencje sezonowo-wiekowych zmian w liczbie leukocytów i erytrocytów $(R B C)$ są więc przeciwne (Fig. 1). Zmiany w bezwzględnej liczbie limfocytów i neutrofilów mają przebieg paralelny do zmienności liczby WBC (Fig. 1). Profil krwi jest u ryjówek limfocytowy, przy czym u młodych procent limfocytów jest wyższy, a neutrofilów niższy, niż u przezimków (Fig. 4). Wskaźnik $L / N$ jest u młodych istotnie wyższy niż u przezimków (Tabela 2). W krwi obwodowej występują młodociane formy granulocytów, głównie metamielocyty i granulocyty niepodzielone. Jesienno-zimowe nasilenie tych zmian jest prawdopodobnie związane z przeciążeniem układu krwiotwórczego silną erytrocytozą (Tabela 2, Fig. 5). Mniejszemu ciężarowi ciała $S$. minutus odpowiada większa liczba $R B C$ i mniejsza liczba WBC, niż u $S$. araneus (Fig. 3). 